Marquette University

e-Publications@Marquette

Theology Faculty Research and Publications

Theology, Department of

9-1-1997

\title{
John Courtney Murray and Postconciliar Faith
}

Thomas Hughson

Marquette University, thomas.hughson@marquette.edu

Published version. Theological Studies, Vol. 58, No. 3 (September 1997): 480-508. DOI. (C) 1997 Theological Studies, Inc. Used with permission. 


\title{
JOHN COURTNEY MURRAY AND POSTCONCILIAR FAITH
}

\author{
THOMAS HUGHSON, S.J.
}

\begin{abstract}
[Editor's Note: The author situates his study of Murray against the background of recent unfavorable criticism about his standing in American Catholicism. He then identifies Murray's approach to faith through an analysis of the notion of "voluntary dynamic," locating it within several contexts and showing its close relationship to the teaching of Vatican II. Special attention is given to the council's shift from the freedom of faith to the dignity of the believer as image of God.]
\end{abstract}

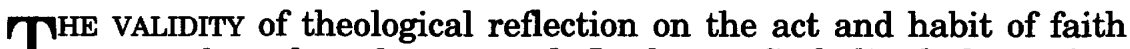
1 cannot be taken for granted. Lutheran-Catholic dialogue has drawn attention to an absence of contradiction between Luther's concept of faith as a comprehensive reception of justification and the Catholic concept of faith as one of three theological virtues by which the justified relate immediately to God. ${ }^{1}$ If fundamental theology nonetheless proceeds in accord with the Pauline triad of faith, hope, and charity, ${ }^{2}$ this is not to ignore the intrinsic unity of the Christian way of life or to counteract the Lutheran perspective. The three theological virtues simply spell out basic modes in one, complete reception of God,

Thomas Hughson, S.J., received his doctorate in theology at the University of St. Michael's College, in the Toronto School of Theology. He is now associate professor of systematic theology at Marquette University. His interests lie especially in the area of christology and ecclesiology. He has contributed the essay "Murray and the People: A Beginning," in John Courtney Murray and the Growth of Tradition, ed. Leon Hooper and Todd David Whitmore (Sheed \& Ward, 1996).

${ }^{1}$ See H. George Anderson et al., ed., Justification by Faith: Lutherans and Catholics in Dialogue VII (Minneapolis: Augsburg, 1985). The "Common Statement" remarked that "By broadening the definition of faith beyond intellectualistic concepts prevalent in modern Scholasticism, the council left open the possibility that faith might include the entire response of the faithful to justifying grace" (no. 73, 42). Theologians from the Lutheran and the Catholic churches actualized this possibility at the end of their "Common Statement" when they agreed that "Justifying faith cannot exist without hope and love; it necessarily issues in good works. Yet the justified cannot rely on their own good works or boast of their own merits. ..." (no. 156, 71).

${ }^{2}$ For Pauline and Deuteropauline references, see 1 Thess 1:3; 5:8; Eph 1:15-18; 1 Cor 13:13; Col 1:4-6; Heb 10:22-24. Dieter Lührmann states that "Paul interprets the triad in Rom. 5: 1-5 in the sense of his doctrine of justification: justification by faith (5:1), hope in the glory of God (5:2), grounded in the gift of God's love (5:5). The three concepts are fulfilled, according to their context, through justification" ("Faith: New Testament," in The Anchor Bible Dictionary, ed. Daniel Noel Freedman [New York: Doubleday, 1992] 2.749-58, at 754). 
Christ, gospel, and justification. ${ }^{3}$ Moreover the Pauline distinction has given rise to patristic, scholastic, and modern theologies of faith. Even if that warranted reflection on faith, still Avery Dulles's coverage of its theological history ${ }^{4}$ might ground a suspicion that little remains unthought and unsaid on the matter. And yet, however large the shadow cast by the Church's theological compendium, the law of incommensurability keeps that heritage open to the future. Faith, after all, is first and last a divine gift exceeding the best understandings and most balanced doctrines yet formulated. Every aspect, therefore, lies open to continual discovery and new appreciation.

More than that, changes in Church and culture commend, sometimes demand, that theology revisit faith no matter how assured or complete the doctrine. Catholicism since Vatican II has inaugurated those kinds of changes. Communion ecclesiology has deepened the Church's self-understanding and has initiated renewal of many structures (e.g. the episcopacy and parishes) in the ecclesial context of faith. A renewing Church in its turn has redefined church and culture relationships in, for example, Poland, Spain, Brazil, and the United States. Jose Casanova ${ }^{5}$ shows that conciliar influence reconfigured social missions. Conciliar renunciation of establishment has lifted the fulcrum of ecclesial influence in the temporal order out of the political and put it into the social sphere. This too makes a difference in the situation of faith that is worth examining. This article, however, heads in a different direction. Following a path through the thought of John Courtney Murray (1904-1967), it proposes that Vatican II also has affected the interior act and habit of faith.

When Murray addressed the subject of faith, he focused principally on its voluntary dynamic. The genre of the post-Tridentine analysis of faith led reflection in that direction. From his 1937 dissertation on the Cologne theologian Matthias J. Scheeben ${ }^{6}$ to the publication of The Problem of God, ${ }^{7}$ he worked within that genre's typical concentration on the genesis of faith. An apologetic orientation led the genre, the

${ }^{3}$ Karl Rahner remarks that the three supernatural, infused virtues "are specified by being the basic modes of increasing acceptance of the divine self-communication by grace and of directing ... spiritual, personal life towards the trinitarian God of eternal life by sharing in God's life itself" "Virtue," in Sacramentum Mundi: An Encyclopedia of Theology 6 (New York: Herder \& Herder, 1970) 337-47, at 338).

${ }^{4}$ Avery Dulles, The Assurance of Things Hoped For: A Theology of Christian Faith (New York: Oxford University, 1994).

5 Jose Casanova, Public Religions in the Modern World (Chicago: University of Chicago, 1994).

'John Courtney Murray, "Matthias Joseph Scheeben's Doctrine on Supernatural, Divine Faith: A Critical Exposition," in The Doctoral Dissertation of John Courtney Murray: Matthias Scheeben on Faith, ed. Thomas Hughson (Lewiston, N.Y.: Edwin Mellen, 1987).

${ }^{7}$ John Courtney Murray, The Problem of God: Yesterday and Today (New Haven: Yale University, 1964); the book originated in the St. Thomas More Lectures at Yale in the winter of 1962. 
predecessor to today's fundamental theology, to concern for clarity about crossing the threshold of faith. His postconciliar turn to the ecclesiological dimension of belief and unbelief was not disconnected from consideration of their voluntareity. Murray's publications on faith are relatively few, ${ }^{8}$ though rich; so there is no surprise in the fact that recent surveys of the topic in fundamental theology 9 have left his work out of account. ${ }^{10}$ Although far from a complete theology of faith, his principle that faith has a voluntary dynamic since love for God causes assent to revelation is open to postconciliar reception.

The first part of my article situates this reading of Murray against the background of some recent criticism about his standing as a paragon of Catholicism in the U.S. In the second part, I discuss the centrality of the voluntary dynamic for Murray's approach to faith. The third and fourth parts illustrate specific ways he interpreted that dynamic. I then argue for bringing an implied historical consciousness of love to the surface so that, in the last section, I can propose a hypothesis relating to the effect that Vatican II has had on the voluntareity of faith.

${ }^{8}$ In addition to the works already mentioned, see "The Root of Faith: The Doctrine of M. J. Scheeben," TS 9 (1948) 20-46; The Problem of Religious Freedom, Woodstock Papers 7 (Westminster, Md.: Newman, 1965), and an earlier, shorter form, "The Problem of Religious Freedom," TS 25 (1964) 503-75; "Freedom, Authority, Community," America 115 (December 3, 1966) 734-41; "The Status of the Nicene Creed as Dogma," Chicago Studies 5 (1966) 65-80; "The Danger of the Vows: An Encounter with Earth, Woman, and the Spirit," Woodstock Letters 116 (1967) 421-27; "Freedom in the Age of Renewal," American Benedictine Review 18 (1967) 319-24; "A Will to Community," in Theological Freedom and Social Responsibility, ed. S. F. Bayne (New York: Seabury, 1967) 111-16. Other writings have theological components. For an account of Murray's teaching duties in dogmatic theology at Woodstock College, see The Doctoral Dissertation of John Courtney Murray, "Introduction" no. 5, 41.

${ }^{9}$ Faith or an approach to it remains subject matter for fundamental theology despite variants in method. See David Tracy, Blessed Rage For Order (New York: Crossroad, 1975) and The Analogical Imagination (New York: Crossroad, 1981); Johann Baptist Metz, Faith in History and Theology: Toward a Practical Fundamental Theology (New York: Crossroad, 1980); Gerald O'Collins and René Latourelle, ed., Problems and Perspectives of Fundamental Theology (New York: Paulist, 1980); Francis Schüssler Fiorenza, Foundational Theology: Jesus and the Church (New York: Crossroad, 1984) and "Fundamental Theology," in New Dictionary of Theology, ed. Joseph Komonchak et al. (Wilmington, Del.: Glazier, 1989) 408-11; Avery Dulles, The Craft of Theology: From Symbol to System (New York: Crossroad, 1992). For an overview and argument for a specific subject matter, method, and identity, see René Latourelle, "Fundamental Theology: History and Specific Character," in The Dictionary of Fundamental Theology (New York: Crossroad, 1994) 324-32.

${ }^{10}$ John O'Donnell, "Faith," in New Dictionary of Theology 375-86; Monika Hellwig, "A History of the Concept of Faith," in Handbook of Faith, ed. James Michael Lee (Birmingham, Ala.: Religious Education, 1990) 3-23; Carroll Stuhlmueller, "The Biblical View of Faith: A Catholic Perspective," ibid. 99-122; Avery Dulles, "The Systematic Theology of Faith: A Catholic Perspective," ibid. 142-63; Avery Dulles, "Faith and Revelation," in Systematic Theology: Roman Catholic Perspectives 1, ed. Francis Schüssler Fiorenza and John P. Galvin (Minneapolis: Fortress, 1991) 89-128; Gilles Langevin, "Faith," in Dictionary of Fundamental Theology 309-15; Avery Dulles, The Assurance of Things Hoped For. 


\section{MURRAY AND HIS RECENT CRITICS}

Both his dissertation on Scheeben and The Problem of God figure in a recent article on the theological sources for Murray's ethics. ${ }^{11} \mathrm{~J}$. Leon Hooper reads the texts as evidence that Murray formulated his ethical principles within the moral universe of Roman Catholicism, not on a natural-law basis outside time, faith, and community. Murray's ethics presupposed and implied the unified whole of the content of faith carried by Catholic tradition. Hooper's approach indicates the primacy of faith as the horizon within which Murray argued philosophical, historical, and jurisprudential as well as theological principles. Hooper's support of a strong rather than weak contribution from faith in his ethics encourages further inquiry into Murray's theological positions. Another interpretation of Murray, however, renders the inquiry futile. Some, whose criticisms echo opposition to Murray in the $1950 \mathrm{~s},{ }^{12}$ seek to discredit his contribution and to nullify its influence. ${ }^{13}$ In their view his entire vision consisted in a theologically fatal compromise which tailored Catholic faith to the contours of an American status quo. Understandably disturbed by signs that Catholics have overadjusted to American culture, ${ }^{14}$ they pin the blame on Murray as the most guilty sponsor of American Catholicism's decline into a comfortable but spiritually flaccid accommodation to modern, especially American, liberal ideology. ${ }^{15}$

11 J. Leon Hooper, "Theological Sources of John Courtney Murray's Ethics," TS 57 (1996) $19-45$.

${ }_{12}$ See Donald E. Pelotte, S.S.S., John Courtney Murray: Theologian in Conflict (New York: Paulist, 1975) on Murray's contretemps with the American Ecclesiastical Review.

${ }^{13}$ Michael J. Schuck, "John Courtney Murray's Problematic Interpretations of Leo XIII and the American Founders," The Thomist 55 (1991) 592-612; William Gould, "The Challenge of Liberal Political Culture in the Thought of John Courtney Murray," Communio 19 (1992) 113-44; David L. Schindler, "Religious Freedom, Truth, and American Liberalism: Another Look at John Courtney Murray," Communio 21 (1994) 696-741.

${ }^{14}$ Robert Booth Fowler comments that both American Judaism and American Catholicism are en route to becoming "individualistic religions. People may be Catholic but they define that Catholicism now in their own terms," with the result that "Catholics and Jews are mostly Protestant . . . in this quintessential liberal Protestant land" ("Religion and Liberal Culture," in Religion, Public Life and the American Polity, ed. Luis E. Lugo [Knoxville: University of Tennessee, 1994] 201-21, at 209). Is this the case? See an intriguing argument for a distinctively "Catholic ethic" paralleling Max Weber's "Protestant ethic" in John Tropman, The Catholic Ethic in American Society: An Exploration of Values, foreword by Rembert Weakland, O.S.B. (San Francisco: Jossey-Bass, 1995). The Catholic ethic "is oriented toward sharing," whereas Weber considered the Protestant ethic "oriented heavily to work, wealth, and achievement" (xiii). Robert Bellah et al. note that the Catholic tradition has "an emphasis on the common good [that] precludes the exclusion of anyone from society's care and concern" (Habits of the Heart: Individualism and Commitment in American Life, updated ed. [Berkeley: University of California, 1996] x).

${ }^{15}$ Of course, as Jean Bethke Elshtain observes, "there is no single, shared understanding of the self that grounds all forms of liberal theorizing"; instead, there are Kant's deontological liberalism, Bentham's utilitarianism, and the saturation of America in "ultra-liberalism" whose "vision of the self flows from seventeenth century contractarian 
For Michael Schuck, this means Murray adopted a liberal model of the self in society. According to William Gould, Murray's political philosophy imbibed too much liberal political culture. David L. Schindler argues that Murray grounded his argument for religious liberty in "nature's primitive 'indifference' toward God." According to Schindler, Murray's sharp distinction between nature and grace views nature, freedom, and the state as first of all in a condition of neutrality or indifference to God and religious truth. Schindler thinks that Murray's affirmation that government is incompetent (Murray did not say "indifferent") ${ }^{17}$ in matters of religion presupposes a concept of nature related to God through grace alone, as if it were not dependent because of creation. He supposes that Murray, on that basis, constructed a natural, autonomous freedom disconnected from the reality and knowledge of God. Consequently, "for Murray, it is (logically) possible for the meaning of freedom to be engaged without implicating the question of God's truth."18 Either this interpretation of Murray's concept of nature and truth is correct or Murray adheres to Aquinas's natural-law principles: that actually existing created natures depend on God for existence and operation as well as tend toward God; and that natural law is the rational creature's participation in God's eternal law. But Murray's Thomist natural-law theory is plain to see and has often been remarked on. So Schindler's reading is incorrect. It reads Murray out of the task of actualizing a postconciliar, American Catholic communion ecclesiology, when in fact his work could be among resources for it.

The charge that Murray colluded with liberal ideology calls for some response. It is clear that Murray endorsed political institutions which he forthrightly attributed to a broad, liberal, Western Christian tradition of church-and-state dualism, of law as reasonable, and of the rule of law as the basic activity of the state. This liberal tradition engendered the gradual realization, through suffering, that religious liberty belongs to human dignity. But did this plunge Murray into 19th- and

discourse, a doctrine linked to the names of Hobbes and Locke (very different thinkers, to be sure)" ("Catholic Social Thought, the City, and Liberal America," in Catholicism and Liberalism: Contributions to American Public Philosophy, ed. David Hollenbach and Bruce Douglass [Cambridge; Cambridge University, 1994] 151-71, at 154).

${ }^{16}$ Schindler, "Religious Freedom, Truth, and American Liberalism" 705.

${ }^{17}$ See Murray's accomodationist position on the school-aid question and his opposition to Supreme Court reasoning in the Everson (1947) and McCollum (1948) cases (We Hold These Truths: Catholic Reflections on the American Proposition [New York: Sheed \& Ward, 1960] 143-54). He endorsed the statement from the Zorach case (1952) that government "respects the religious nature of the people and accommodates the public service to their spiritual needs" (ibid. 151). It was a signature theme of Murray's that the "first truth to which the American Proposition makes appeal ... in that landmark of Western political theory, the Declaration of Independence ... [is] the sovereignty of God over nations as well as over individual" people (ibid. 28).

${ }^{18}$ Schindler, "Religious Freedom, Truth and American Liberalism" 734. 
20th-century "doctrinaire liberalism"? ${ }^{19}$ Individualism is essential to liberalism of this sort. If individualism was missing from Murray's practice and theory, then his work cannot have been in collusion with liberal ideology. Did Murray somehow absorb modern American individualism, then take it as a premise in his life and work? If so, this would have flawed Murray's theology of faith in basic principle, because adherence to a cultural tendency, erroneous at that, would have preempted faith as the supervening act, light, and content interpreting life in the culture. Murray would have made American culture the last word on faith, instead of considering faith as the norma non normanda for believers' theory and practice. But on the contrary, his Catholic practice and theory alike excluded liberal individualism. ${ }^{20}$

The concept of practice (praxis) can be distinguished from technical implementation of preconceived theory (techne). In regard to Murray, a concept of practice can be broadened from Hooper's emphasis on Murray's learning from engaging in public discourse. It can include his free, public self-disposition in and through the explicitly religious structures of Catholic life as a vowed member of a religious congregation. This is to open the concept of practice to spirituality on the principle that a lived relationship to God (practice) grounded Murray's theoretical writings (theory). This can be understood by analogy with the role that Ignatian spirituality (practice) played in the theology (theory) of Karl Rahner. ${ }^{21}$ Murray entered a Jesuit novitiate at the age of 16, took public vows at 18, and was ordained a priest in 1933. From 16 until his death at 63 in 1967, he lived in a religious congregation.

${ }^{19}$ Joseph Komonchak points to a "doctrinaire liberalism" that departed from what Murray considered a "broad liberal tradition" of the West, because it sought to exclude religion from public life. Komonchak helpfully points to a "distinction between liberal political structures, which the church can accept, and a liberal ideology, which it must repudiate" (Vatican II and the Encounter between Catholicism and Liberalism," in Catholicism and Liberalism 76-99, at 89).

${ }^{20} \mathrm{On}$ individualism and communitarianism in political theory see, e.g., Michael Walzer, "The Communitarian Critique of Liberalism," Political Theory 18 (February, 1990) 6-23; Amy Gutmann, "Communitarian Critics of Liberalism," Philosophy and Public Affairs 14 (1985) 308-22. See also Schuck, That They Be One: The Social Teaching of the Papal Encyclicals 1740-1989 (Washington: Georgetown University, 1991); David Hollenbach, "The Common Good in the Postmodern Epoch: What Role for Theology?" in Religion, Ethics, and the Common Good, ed. James Donohue and M. Theresa Moser, R.S.C.J., The Annual Publication of the College Theology Society 41 (Mystic, Conn.: Twenty-Third, 1996) 3-22. Here, too, the essays in Catholicism and Liberalism and in Celebration and Challenge: One Hundred Years of Catholic Social Teaching, ed. John Coleman (Maryknoll, N.Y.: Orbis, 1991) are germane.

${ }_{21}$ For the influence of Ignatian spirituality on Rahner's theology, see Harvey Egan, "Rahner's Mystical Theology," in Theology and Discovery: Essays in Honor of Karl Rahner, S.J., ed. William Kelly (Milwaukee: Marquette University, 1980); Karl Rahner in Dialogue: Conversations and Interviews 1965-1982, ed. Paul Imhof et al. (New York: Crossroad, 1986); Leo O'Donovan, "Orthopraxis and Theological Method: Rahner," in Catholic Theological Society of America, Proceedings 35 (1980) 47-65; Paulette Skiba, "Karl Rahner's Transcendental Christology: A Resource for Catholic Social Teaching?" (unpublished dissertation, Marquette University, 1997). 
His singular abilities and public prominence did nothing to diminish the reality of participation in a common life and mission.

For example, he owned no private property. He earned no personal income, amassed no nest-egg for bequeathal to heirs, and received what resources he used from goods held in common. He took up professional tasks of teaching, writing, editing, delivering public addresses, participating in the debates of American public life, not to mention liturgical and spiritual ministries, under a vow of obedience. He multiplied relationships of service and friendship on the basis of something other than a strategy for advancing self-interest. His labors contributed to and were part of the common good of the Catholic Church and of American society. His free self-disposition within a vow of obedience meant that his self-direction never ruled out readiness to heed the counsel and authority of superiors in his congregation or the Church. ${ }^{22}$ It could and did bring self-sacrifice, understood as a mode of fidelity to Christ. This was evident when he bore an official silencing in $1954 .^{23}$ Murray's obedience did not exemplify utilitarian or expressive individualism. Consequently, there is no plausible way to construe Murray's 47 years as a member of a religious congregation as an exercise in American individualism. ${ }^{24}$

Rather, the inner form of his life-practice was imitatio Christi, an apostolic discipleship with a clear ecclesial dimension. ${ }^{25}$ His contribution to the pastoral mission of the Church through priestly ministry in retreats, liturgies, and preaching, not well-enough known, ${ }^{26}$ indicates a practical faith-understanding oriented to the breadth of the Church, not to individualistic preoccupation with his own salvation. So it would be massively inconsistent if his theory on religious liberty accepted or advocated individualism of any sort. Suspicion that ideology may capture theory if not practice raises the possibility that individualism gained entrance to his texts despite his manner of life. Did his writings on religious liberty in particular, like his practice, exclude a liberal model of the self? Murray's diachronic negation of "Continental Lib-

\footnotetext{
${ }^{22}$ Murray meditated on the risk essential to this kind of free self-disposition in "The Danger of the Vows: An Encounter with Earth, Woman and the Spirit,"Woodstock Letters 116 (1967) 421-27; his portrayal of the feminine was not ahead of its time.

${ }^{23}$ See Pelotte, John Courtney Murray.

24 Jean Bethke Elstain comments that “Atomism's absolutizing of choice and its celebration of radical autonomy all cast suspicion on ties of reciprocal obligation or mutual interdependence and help to erode the traditional bases of personal identity and authority in families and civil society alike" ("Catholic Social Thought" 155).

${ }^{25}$ On the ecclesial dimension in general, see Avery Dulles, "The Ecclesial Dimension of Faith," Communio 22 (1995) 418-32.

${ }^{26} \mathrm{He}$ was a sought-after preacher of retreats. The text of his sermon for the Red Mass in Washington, D.C., February 1953 (Murray Archives, file 2-294) witnesses to his homiletic interests. See bibliographical entries, 1953 f and 1956i, in "Works by John Courtney Murray, S.J.," in J. Leon Hooper, Bridging the Sacred and the Secular: Selected Writings of John Courtney Murray, S.J. (Washington: Georgetown University, 1994) 343-55.
} 
eralism" $(1937)^{27}$ and "liberalist individualism" $(1960)^{28}$ is evident and undeniable. The better-known 1960 position will be noted here.

We Hold These Truths took issue with Locke on the origin of the state out of an allegedly original, asocial, apolitical condition of human existence. ${ }^{29}$ Murray objected that an inherently presocial self inhabiting a prepolitical state of nature was a figment of philosophical imagination nowhere to be found in fact. He characterized this view of the person as follows: "In the state of nature, man appears with complete suddenness as a full-grown individual, a hard little atom in the midst of atoms equally hard, all solitary and self-enclosed, each a sociological monad." ${ }^{30}$ Locke's postulate of a "state of nature" of this sort, and his theory of the origin of the state in a contract aimed at protection of the life and private property of individualist contractees, Murray thought, corroded rather than sponsored or supported American democracy. So he pointed out the social aspect of the human rights protected but not invented by the Bill of Rights. America's founders, he argued, recognized civil liberties as essential to the success of democratic selfgovernance. The free-exercise clause in the First Amendment, for example, brought social benefits and was essential to the common good of American society, not just to the private good of individuals. Free exercise of religion protected the freedom of religions to teach morality to their members who, because they could govern their own lives according to conscience, were capable for tasks of national self-governance. In general, Murray always sought to "establish sociality as an initial defining condition even for rights as immunities."

Accordingly, he rejected "liberalist individualism" as a foundation for the right to religious liberty. On the contrary, liberalism produced a theory of the person and of knowledge able to serve as a premise for the recrudescence of a monist state inimical to religious liberty. Modern monism, or totalitarianism, was the coercive claim by a state (e.g. the French Third Republic, the Soviet Union, the Third Reich) to supreme, undivided authority over all areas of social existence. Murray, with Pope Leo XIII, saw rationalist individualism as its theoretical and practical starting point. As rationalism it ruled out any truth or value not fully derived from human reason; as individualism it referred to the competence of an individual's rational capacity. In practice, it al-

${ }^{27}$ See, The Doctoral Dissertation of John Courtney Murray 22-26.

${ }^{28}$ Murray, We Hold These Truths 309.

${ }^{29}$ For the debate over Locke's influence on the founding of America, see Jerome Huyler, Locke in America: The Moral Philosophy of the Founding Era (Lawrence: University of Kansas, 1995); Murray approximated the view Huyler rejects, namely that "classical republicanism spoke of conceptions and concerns that were largely foreign to Locke's discourse, and vice versa" (ibid. ix).

${ }^{30}$ We Hold These Truths 303. For an earlier proposal that the "age of individualism has ended," see "The Construction of a Christian Culture" (1940), in Hooper, Bridging the Sacred and the Secular 101-23, at 111.

${ }^{31}$ J. Leon Hooper, The Ethics of Discourse: The Social Philosophy of John Courtney Murray (Washington: Georgetown University, 1986) 154. 
lowed the state to assume the role of reason writ large, coercive and intolerant of claims to truth and value beyond those presented by the state.

He recalled that "it was against this type of liberalist individualism-as positing a social and juridical monism and a concept of the absolute autonomy of the individual human reason-that the Catholic Church directed her uncompromising attacks during the nineteenth century, under appeal to the traditional natural law."32 The claim that political authority had full, indivisible, and supreme authority in all of social existence represented a rejection of what Murray considered the core of a genuinely liberal tradition, that is, church-and-state dualism and natural law. Both Nazism and Communism were types of monism, and both predictably sought to control or extirpate the Church to prevent the public presence of another authority teaching about self, society, state, and justice. Both eliminated religious liberty. His American Catholic opposition to Nazism and Communism stemmed from a principled affirmation that the basic political institutions of America were in harmony with Catholic morality. This made his unreserved identification with the American cause in World War II and in the Cold War something other than an example of reducing Catholic faith to the American way of life (Schuck), to a liberal political culture (Gould), or to liberal ideology (Schindler).

Moreover, We Hold These Truths opposed the hegemony of the Enlightenment critique of tradition. ${ }^{33}$ He interpreted the emergence of Western legal and political protection for religious liberty as a consequence primarily from tradition understood to include the institutionalization, and not only the verbal transmission, of the gospel. And so the original subject of religious liberty was the whole, institutionally organized Church. Assertion and acquisition of its freedom for life and witness was the tree in whose shade people came to see and claim individual religious liberty. Murray disagreed with interpretations of the religious clauses as if they implemented preconceived theoretical concepts already deposited in documents, even the Bible. Instead he held that gradual, progressive formation of Western consciousness and political institutions by church-and-state dualism led the way. The path ran from the missions of Son and Spirit in the advent of the Church to Pope Gelasius's spelling out of church-and-state dualism; from there to medieval principles on the consent of the governed and the rule of law, through the Magna Carta in 1215 and English legal tradition, over to New World colonists' grass-roots appropriation of the rights of an Englishman, up through their resistance to state control of religion, into the founders' legal realism in a pluralist society, and

\footnotetext{
${ }^{32}$ We Hold These Truths 309.

${ }^{33}$ See, e.g., his defense of truth in the form of remembered wisdom when discussing America's "first prejudice" for non-establishment and religious liberty (ibid. 46-48).
} 
arrived at resultant First Amendment religion clauses. Murray read the emergence of civil protection for religious liberty mostly as a practical lesson learned the hard way in a Western Christian history leavened by church-and-state dualism. Even where Murray may err, as I think he did by slighting the contribution from free-church, especially Baptist, sources, he did not tend toward but away from liberal individualism.

We Hold These Truths argued an American Catholic alternative to, not version of, Hobbes, Locke, Rousseau, 19th-century rationalism and 20th-century consumerism. ${ }^{34}$ The case for harmony between Catholicism and American political institutions, particularly the religion clauses of the First Amendment, did not consist in subordinating Catholic principles to liberal individualism. He formulated a synthesis of Catholic with republican principles, ordered according to the churchand-state norm that the spiritual (God, revelation, Christ, Church, grace, faith, conscience) is primary in dignity. ${ }^{35}$ The 1990 s objection that Murray's writings contain liberal ideology to the detriment of faith is as invalid as was Francis J. Connell's 1950 charge that Murray's position on the First Amendment gave short shrift to the economy of salvation and the kingship of Christ. On the contrary, as Hooper indicated, Murray's thought on religious liberty too developed within the horizon of Catholic faith. There are, indeed, real problems and questions in regard to postconciliar appropriation of Murray. But his putative conforming of Catholic faith to a liberal ideology of the individual is not one of them. How, then, did Murray understand the act of Catholic faith?

\section{THE VOLUNTARY PRINCIPLE: LOVE MOVES ASSENT}

The theological impulse animating Murray's theology of faith was a response to Dei Filius, the Constitution on the Catholic Faith promulgated by Vatican I in 1870 . The council had declared that "we are obliged to render by faith a full submission of intellect and will to God when he makes a revelation."36 This teaching could be read as if faith were an assent of mind for which a separate moral act of submission to

\footnotetext{
${ }^{34}$ Individualism, observes Jean Bethke Elshtain, is "solidified by market images of the sovereign consumer" ("Catholic Social Thought" 155).

${ }^{35}$ See Charles Taylor, "Religion in a Free Society," in Articles of Faith, Articles of Peace, ed. James Davison Hunter and Os Guinness (Washington: Brookings Institution, 1990) on Protestant fusing of religious and republican convictions in 17th-century England and Holland. Taylor remarks, "In the case of the Puritan movements in the English Civil War, a Parliamentary case begins to be stated in part in terms of the old republican outlook. Milton was a Christian civic humanist" (101). Murray, it could be said, was an American Catholic civic humanist.

36 "Because man depends entirely on God as his creator and lord and because created reason is wholly subordinate to uncreated Truth, we are obliged to render by faith a full submission of intellect and will to God when he makes a revelation" (Dogmatic Constitution on the Catholic Faith [Dei Filius], in The Decrees of Ecumenical Councils 2: Trent to Vatican II, ed. Norman P. Tanner [Washington: Georgetown University, 1990] 807). Vatican II incorporates part of the Vatican I statement: 'The 'obedience of faith' (Rom.
} 
God set the stage. Joseph Kleutgen's reading of Vatican I, for example, tended to identify faith with intellectual assent. In response, Matthias J. Scheeben (1835-1888), ${ }^{37}$ Pierre Rousselot (1878-1915), ${ }^{38}$ and then Murray seized upon an essential role played by love for God. Love for God was elicited by the grace of faith and moved assent to revelation. Murray concentrated on the voluntary dynamic in faith in order to counteract one-sidedly intellectualist interpretations of Vatican I that ignored or minimized a key theme from theological tradition.

One popular analysis of the assent of faith ran as follows. First, once a person has taken account of signs, testimonies, arguments, etc., that make revelation credible, there is an assent to revelation precisely as divine truth, as the way things are ${ }^{39}$ Holding these truths is human participation in divine wisdom and the knowledge of the blessed. The gospel is good news first of all because it is true news. Still, the gospel as a whole, but above all the strict mysteries of faith, exceed that which can be learned from created reality. How can a human being assent to the gospel as true if that assent does not conclude from prior truth in the way people conclude to all other judgments on truth? Can there be an assent to divine truth so different from all other judgments on what is real? Faith does not conclude to revealed truth from some other truth gained from created reality. Faith does not conclude, because it cannot. There is no prior truth a grasp of which enables someone to pass to faith as a conclusion. Then if not on the basis of a true premise or from its mediation by testimony open to corroboration, how can a person's act of judgment actually come to affirm that, "Yes, I accept that as true"?

16:26; cf. Rom. 1:5; 2 Cor. 10:5-6) must be given to God as he reveals himself. By faith man freely commits his entire self to God, making 'the full submission of his intellect and will to God who reveals ...'" (Dogmatic Constitution on Divine Revelation [Dei Verbum] no. 4, in Vatican Council II: The Conciliar and Post-Conciliar Documents, gen. ed. Austin Flannery [Northport, N.Y.: Costello, 1988] 752).

${ }^{37}$ For the texts of Scheeben that Murray considered, see the bibliography in The Doctoral Dissertation of John Courtney Murray 257-59. Available now but not when Murray wrote in 1937 are The Mysteries of Christianity, trans. Cyril Vollert (St. Louis: B. Herder, 1946); Nature and Grace, trans. Cyril Vollert (St. Louis: B. Herder, 1954); Gesammelte Schriften, ed. Josef Höfer, Martin Grabmann et al., 8 vols. (Freiburg: Herder, 1949-67). Scholarship on Scheeben likewise has increased; see among others: Eugen Paul, "Matthias Joseph Scheeben (1835-1888)," with bibliography, in Katholische Theologen Deutschlands im 19. Jahrhundert 2, ed. Heinrich Fries and Georg Schwaiger (Munich: Kösel, 1975); Wegbereiter heutiger Theologie; Matthias Scheeben (Cologne: Styria, 1976); Karl-Heinz Minz, Pleroma Trinitatis: Die Trinitätstheologie bei Matthias Joseph Scheeben (Frankfurt: Lang, 1982).

${ }^{38}$ In the dissertation Murray referred only in passing to Les yeux de la foi by Pierre Rousselot, S.J.; see the volume containing the two works of Rousselot, The Eyes of Faith, trans. Joseph Donceel, and his Answer to Two Attacks, trans. Avery Dulles (New York: Fordham University, 1990). Focus on the role of the will in faith was also paramount for Rousselot; see John M. McDermott, Love and Understanding: The Relation of Will and Intellect in Pierre Rousselot's Christological Vision (Rome: Gregorian University, 1983).

${ }^{39}$ See Thomas Aquinas, Summa theologiae 31: Faith (2a2ae, 1-7), Latin text and English translation, ed. T. C. O’Brien (London: Eyre \& Spottiswoode, 1974). 
The answer from Augustine to Aquinas had been that the act of faith springs from a love for God that is the first effect of the grace of faith. Augustine said, "It is love that asks; it is love that seeks; it is love that makes one adhere to revelation; and it is love that maintains the adherence once it is given." ${ }^{40}$ Consequently, the faith that justifies "is a loving submission to Christ the Lord (credere Christo) and a movement of the soul that seeks union with Christ (credere in Christum)."41 This characterization appealed to the Fourth Gospel's description of believers being drawn by the Father $(6: 44,65 ; 8: 32) .{ }^{42}$ Later, the Council of Orange declared that the initium fidei was a "trustful adherence" (credulitatis affectus) "by which we first enter into communion with God" (Canon). ${ }^{43}$ The trusting love, said Augustine and Orange, is "not a product of our natural powers but is a gift of the Holy Spirit at work in our hearts." "Aquinas followed suit when he too affirmed a graced love interior to faith. This is not to say that he conducted an analysis simply on the authority of Augustine but to identify his consistency with Augustine.

Aquinas, however, often referred to the role of the will in terms of a "command of [by] the will." In response to the question whether it is meritorious to believe, he wrote that "to believe is an act of mind assenting to the divine truth by virtue of the command of the will as this is moved by God through grace." ${ }^{25}$ And so, reasoned Aquinas, faith is a free and therefore meritorious act. Elsewhere he conceived the act of will in faith as an "affection" which "determines" the intellect stating, for example, that "the beginning of faith is in affection insofar as the will determines the intellect to assent to the things of faith." ${ }^{.46}$ This willing, he clarified, "is not an act of charity nor of hope but is a certain appetite for the good promised." ${ }^{47}$ Mohler explained this to mean, "the will is drawn on by the supernatural good, which is God ... in the beatific vision," 48 and so drawn, inclines the mind to assent to things it cannot see because God guarantees their truth. Murray followed

${ }^{40}$ Augustine, De moribus ecclesiae 1.17.31, quoted in Dulles, Assurance 26.

41 Dulles, ibid. 26.

${ }^{42}$ See The Doctoral Dissertation of John Courtney Murray 236. Gilles Langevin remarks that "in the Gospel of John, faith is born of the attraction exerted by the Father, who invites human beings to share in the life of the Trinity"; he sums up Pauline teaching on faith by saying that for Paul and Luke "faith proceeds from the eschatological action of God in the raising of Jesus and in the preaching making him known" ("Faith" 309).

${ }_{43}$ Dulles, Assurance 28.

${ }^{45}$ Summa theologiae 2-2, q. 2, a. 9, resp.; trans. T. C. O'Brien 97.

${ }^{46}$ De veritate q. 14, a. 2, ad 10; trans. James A. Mohler, The Beginning of Eternal Life: The Dynamic Faith of Thomas Aquinas, Origins and Interpretation (New York: Philosophical Library, 1968) 147, no. 23.

${ }^{47}$ Ibid. 147.

${ }^{48}$ Tbid. 64. 
Aquinas, though he supported a renewal in patristics, ${ }^{49}$ and described the voluntareity of assent to the Word of God in terms other than Aquinas's "command of the will."50 Emphasis on a voluntary dynamic immanent in the intellectual assent of faith characterized Murray's theology of faith. It was a position that he began to develop as a modification of Scheeben's.

\section{INTERPRETATION: LOVE EXPRESSES FINALITY}

In his "Matthias Joseph Scheeben's Doctrine on Supernatural, Divine Faith: A Critical Exposition" (1937), Murray stressed that Aquinas had pointed to the voluntary dynamic in faith. Murray interpreted this to mean that love was an option for, a self-dedication to, God as supreme good and last end. This option moved assent. His concept incorporated Aquinas's principle of final causality: faith fulfills a human tendency toward God (reditus) and not only a reverence due to God as first efficient cause from which all created being has come forth (exitus). Murray caught sight of Aquinas's situating of faith within the exitus/reditus plan. Faith was the beginning of the salvific return of rational creatures to God by way of union with Christ. His focus on finality opened up a point of departure from Scheeben's theology of faith.

In his Dogmatik (1873) Scheeben had expounded a theology of faith in the service of Vatican I's teaching. The act of belief was for him the supreme instance of creaturely obedience to the Creator, whose authority commands that creatures accept divine revelation as true. Faith fulfilled the fundamental moral duty rational creatures owed to the Creator. Earlier, in Nature and Grace (1861), Scheeben had conceived faith along the lines of the Greek Fathers. Murray noted Scheeben's indebtedness to Maximus the Confessor. ${ }^{51}$ According to this preVatican I approach, faith participated in the Son's knowledge of the Father. Faith was an anticipatory mode of beatific vision that divinized the created understanding. When Vatican I reemphasized the principle of divine and apostolic authority in the Church and underlined faith as obedience, Scheeben refocused his views. In his post-Vatican I theology, faith did not so much participate in the Son's knowledge of the Father as it shared in the Son's self-sacrifice to the Father. Rev-

${ }^{49}$ For indications, see Murray, "Patristic Study," TS 9 (1948) 250-51; "The Christian Idea of Education," an address at St. Louis University, November, 1955, in Hooper, Bridging 133-41; and The Problem of God.

${ }_{50} \mathrm{~J}$. H. Newman likewise saw how central a graced, voluntary dynamic was to the assent of faith. He identified the pia affectio as a devout state of mind disposing a person to welcome the truth of Christ. Because of a spirit of reverence for God a "divinely enlightened mind sees in Christ the very Object whom it desires to love and worshipthe Object correlative to its own affections" (Newman's University Sermons: Fifteen Sermons Preached before the University of Oxford, 1826-1843 [London: SPCK, 1970] 236; quoted in Dulles, Assurance 85).

${ }^{51}$ See The Doctoral Dissertation of John Courtney Murray 89 n. 19. 
erent submission to divine authority in an act of faith was a believer's sacrificium intellectus in imitation of Christ's obedience.

Scheeben's Dogmatik stressed this partly in opposition to a rival claim. Some learned people claimed to have arrived at a natural faith from rationally evident premises and evidences. This did not involve obedience to the Creator, repentance for sin, or resolution to live in an amended way. Their type of consent to God, Scheeben warned, contained neither reverent submission nor personal commitment to God. Natural faith did not animate a new way of life and was not to be considered equivalent to the supernatural, divine faith professed by the Catholic Church. Affirmation of revealed truth that did not at the same time involve a change in way of life was not the faith of the Gospels. Scheeben countered that, on the contrary, believing with divine, supernatural faith was the devout fulfillment of a universal moral duty toward the Creator that was incumbent on all rational creatures. This obligation pertained to the order of truth no less than to the order of the moral good. Had not Vatican I taught that created reason is absolutely subject to uncreated Truth? In agreement, Scheeben argued that created reason fulfilled the duty toward uncreated Truth in the obedience of faith. This involved, however, a personal surrender to God in accepting divine revelation as true. Love and commitment characterized the act of belief. It was not an intellectual act disconnected from reverence for God and conversion of life.

On the contrary, Scheeben taught, faith synthesized intellectual and volitional acts, integrated mind and heart. Faith fused obedient love for God with assent to God's revelation as true. This went beyond merely underscoring Vatican I's correlation of divine command (revelation) and creaturely obedience (faith). Scheeben's originality on the point lay in conceiving the command-obedience structure by analogy with parent-child relations. The created reality he used as an analogue to revelation and faith was benevolent paternalism and childlike obedience in family life. The affective dynamic in an act of faith was like the trusting reverence a cherished child had for a beloved parent. The affective dimension of faith was a childlike, trusting reverence for God the Creator (pius credulitatis affectus).

In commanding that revelation be accepted as true on divine authority, God was like a revered parent whose authoritative commands were beneficent and could be so appreciated by the child, though reasons for them might escape the child's understanding. Like a parent directing a child, the Creator placed a demand on all rational creatures crucial to the hearers' good. Faith was like the child's act of receiving the parental injunction as true and worthy of adherence, even if the child could not grasp the reasons for the parental mandate beyond knowing it was good to perform what had been enjoined. With this analogy Scheeben argued that saving faith was far from a rationalist natural faith void of love, dedication, and reverence. It was not the detached, purely cerebral assent which Kleutgen and others had propounded as the authentic meaning of Vatican I. 
Murray endorsed Scheeben's attention to an affective dynamic in faith. But he dropped Scheeben's child-parent analogy. Instead of understanding pia affectio as childlike trust, Murray had recourse to Aquinas's idea of creaturely finality to the Creator. The pia affectio was reverent acceptance of the finite, creaturely condition and concomitant dedication to the Creator. Creaturehood involved finality toward full actualization in the supreme good and last end. Voluntary adherence to God in faith fulfilled and elevated a natural desire for God. The divine act of revealing did something other than let fall onto creatures an external, divine demand for a new kind of obedience.

The gift of faith evoked and enabled a creaturely embrace and transformation of the believer's inherent finality to fulfillment in God, a tendency misdirected by sin and surpassed by grace. Divine grace inclined the heart and enlightened the mind to accept God's Word. The gift initiated conversion, fulfillment, and elevation of the finality in rational human nature toward its Creator, now known as last end. Faith actualized a personally possessed created nature. Faith was not heteronomous submission to One who is simply omnipotent Other. For Murray, faith was entry into a new, definitive and personal relationship with the Creator. Faith was a believer's self-surrender engaged in the form of a divinely enabled self-realization of a created human nature. This was a respectful step beyond Scheeben's interpretation of faith as a childlike sacrificium intellectus in obedience to an external divine command.

For Murray, faith was creaturely obedience. But this obedience heeded the first mode of the Creator's command to rational creatures. The command existed in the mode of created human nature's own finality toward God. The act of faith obeyed this internal structure of human existence no less than it heeded divine authority mediated through biblical teaching and church preaching. Belief accepted the personally possessed finality of human nature. Consequently, faith had an aspect of fidelity and obedience to the believer's own created existence. This made faith an act sui generis rather than a fulfillment of a generic moral duty. The enactment of full creaturely dependence on the Creator also consummated the human self-understanding and self-disposition of the believer as creature. Where Scheeben conceived the consecratory aspect of faith in terms of a child's dedication to carrying out a parental command, Murray saw the consecration of self in light of human finality toward God. Faith was, it can be said on the basis of Murray's text, an adult option to consecrate one's life to God.

Murray's vision of faith placed the believer in teleological relation to God as last end. ${ }^{52}$ This means that God is the goal within all goals, the absolute fulfillment transcending the completion of any act. The absence of that fulfillment is the signature of the mortal pilgrimage of

\footnotetext{
52 The source for this principle is Aquinas; but it is worth noting that it also accords with the "First Principle and Foundation" in Ignatius Loyola's Spiritual Exercises which Murray knew well.
} 
faith. God as last end is the fullness in which and toward which all activities tend. This affirms, though Murray did not develop the point, a tendency toward God prior to faith. This implies that the graced act of love internal to faith is also a conversion of the prior finality. And the emergence of the new love is renewal and elevation of a prior, perhaps inchoate and surely somewhat misguided orientation to God. Creaturely love for God the first cause becomes love for God as last end and source of eternal beatitude.

In addition, Murray's earliest theology of faith was in principle, though not in amount of content, christocentric. Jesus revealed divine authority in a ministry of visible self-giving. Jesus invited hearers to faith but did not simply relay a divine command to believe backed up by powerful signs. The authority with which Jesus acted and taught did not expect or solicit a parent-child relationship with followers. Though Murray did not make the point, it could also be said that faith had a structure leading to friendship. Thus, Murray departed from Scheeben's benevolent paternalism by interpreting the obediential aspect of faith as a co-affirmation of the humanity of the believer. The voluntary dynamic of faith was also its obediential dynamic.

\section{INTERPRETATION: LOVE DEFINES THE BELIEVER}

In 1948, for a slightly revised third chapter of his 1937 dissertation, "The Root of Faith: The Doctrine of M. J. Scheeben," Murray elucidated one particular aspect of faith's voluntary dynamic. The affective dynamic became the "root of faith." His metaphor invoked a principle that was not only an initium fidei conceivable by analogy with efficient causality but also a continuous, immanent influence more like formal causality. Love for God did not just jump-start an act of faith but was an ongoing source for the habit of faith. The Problem of God in 1964 once again made the voluntary dynamic of faith a major theme, this time within a scriptural context. Murray conceived the universal human experience of the problem of God as the substance of the biblical history of Israel.

Though he brought the history forward through the New Testament and into patristic recourse to Greek philosophy, Murray located the problem of God first and foremost in the lived experience of Israel, not primarily in the metaphysical inquiries of Plato and Aristotle. Much less did the problem emerge from the postmedieval, Western transition into modern science and philosophy. The solution to the problem did not consist in a theistic theorem argued precisely as theory, but in an act of free, self-surrendering, and self-defining belief in God-with-usin-Christ. Once again Murray attended to the source of faith in a pretheoretical love for God. What in 1937 and 1948 had been a theme raised in relief against the background of Vatican I had become the golden thread through biblical narratives of faith. 
In the Bible the leading alternative to faith was not reason but ignorance. The Hebrew Scriptures opposed "knowledge of God" to "ignorance of God." This kind of "knowledge" involved a knower's freedom, love, and self-disposition. Such knowing was the full, selfdefining act by the whole person. Murray contrasted this with the usual view by noting that "knowledge of God" was "an affair of the heart, in the biblical sense of the heart as the center and source of the whole inner life in its full complex of thought, desire, and moral decision." ${ }^{33}$ The act of faith originated, then, in the human "heart" whose primal deliberations embraced a "full complex of thought, desire and moral decision." From the heart sprang a life of belief in God which is "knowledge of God" or the refusal known as "ignorance of God." Knowledge or ignorance of God were the two alternatives. Each is formed first of all and characteristically in free, primal, practical selfdefinition, an existential stance. Only then could either become subject matter for theoretical understanding. Despite all the singularities exhibited in Israel's coping with the "problem of God," Murray held that "the Old Testament problematic endures as the permanent religious problematic of all mankind."54 Israel's particularity disclosed something universally human. Israel's struggle revealed, for example, that the root of faith in God lies in free, practically intelligent selfdedication to God. This moves judgment to accept God's Word as true. His basic principle was that "knowledge of God is not an affair of affirmation [intellectual judgment] alone; it is a free engagement in a whole style of life." ${ }^{n 5}$ This was his position on the voluntary dynamic in faith on the eve of Vatican II.

In analyzing various types of atheism Murray showed that voluntareity was not voluntarism. First, atheism had a voluntary dynamic and an intelligible content. Just as knowledge of God was "free engagement in a whole style of life," so too was its opposite. That is, "ignorance of God is not simply a want of knowledge or even a denial; it too is the free choice of a mode of being." ${ }^{56}$ He recalled that "the Bible clearly locates the ultimate root of atheism not in an erroneous judgment of the mind but in an act of choice, made somehow in the name of freedom." choice was for a godless life. This made the choice an act of selfdefinition. Self-definition involved a somewhat knowable way of life, at least as an inner orientation. The choice was practical and existential but not a contentless option for self-expression. Adhering to a theory of reality was, for Murray, a secondary act dependent on the primary act and content of self-definition.

Second, Murray saw that defining the broadest contours of one's life had to do with recognizing oneself or not. In fact, love for God expressed as formal belief in God was the fundamental human act of

${ }^{53}$ Murray, The Problem of God 21.

55 Ibid. 77.

${ }^{54}$ Ibid. 25.

${ }^{57}$ Ibid. 84. 
self-recognition and self-understanding. Likewise, atheism was a matter of human self-understanding and identity. Unbelief no less than belief involved at its most basic level who one understood oneself to be, as well as whether one thought there were or were not sufficient grounds for judging one way or the other on the question whether God exists. Murray explained that "the will to atheism, again like the will to faith, issues forth from the deepest regions of the self, where freedom is more than choice [specific choices], where it is the self recognizing its own existence in the recognition of God or rejecting its own existence in the refusal of God." 58 In the drama of human existence, inside or outside Christianity, the voluntary "root" of belief or unbelief was an act of basic self-definition, personal, and possibly also communal. In the case of faith, love for God as last end was expressed in free self-disposition. But it was love for God immanent in affirmation of something true about self and God.

Because of the priority of this act of free self-definition, whether complete and whole in belief or truncated in unbelief, Murray concluded that "atheism is never the conclusion of any theory, philosophical or scientific." Instead, "it is a decision, a free act of choice that antedates all theories. ${ }^{\text {} 59}$ This fundamental act of choice inspired atheistic philosophies rather than flowing from them as a conclusion. That interpretation was, he thought, "derivative from the Bible." ${ }^{60}$ The act of choice was pretheoretical, but not apart from known content.

What was the content of the fundamental act of self-definition? The content was not primarily that of specific choices. Belief or unbelief was prior to and immanent in specific choices about particular objects. The priority was one of interiority, not of temporal sequence and more like a relation of cause to effect. But if prior to specific choices such as, for example, how to earn a livelihood, whom to marry, whether to seek further education, then what was the content of self-definition? As Murray pointed out by referring to an "engagement in a whole style of life," the definition outlined the journey of one's life. Self-definition as belief affirmed and accepted both one's own self as creature and the divine source as last end. For Murray belief in God affirmed the teleological structure of human existence.

Murray, it is true, did not cast his position in the vocabulary of "correlation" or "dialogue." Yet in 1962 he treated free, practical affirmation that "I am" and "God is" precisely as the believer's affirmative correlation of teleologically structured human existence and divine reality. Conversely, an option for unbelief rejected a teleological interpretation of human existence. Assent to God in faith involved recognizing and accepting the godward structure of human existence. Ac-

58 Ibid. 85.

59 Ibid. 95.

${ }^{60}$ Murray points to a pretheoretical self-disposition prior to argument that therefore could be considered a moment in a personal and social narrative. 
ceptance contained self-recognition. This self-recognition was carried along within the love for God moving assent to the Word of God. The root of faith was love for divine reality as source and last end of the one believing. The graced love for God moving faith was, therefore, an interpretation of the apprehended whole of reality concentrated in a recognition of oneself as open toward the divine.

\section{IMPLICATION: HISTORICAL CONSCIOUSNESS OF LOVE}

The analysis of atheism in Chapter 3 of The Problem of God can be read as implying something else about the voluntareity of faith. Receiving the grace of faith necessarily occurs in a contingent, historical mode with a cultural aspect. The familiar principle that divine reality is received ad modum recipientis is true for receiving the grace of faith. And part of that mode is historical and cultural particularity. The voluntareity of belief, like that of unbelief, has a historically specific, culturally determined element. Murray did not parallel his discussion of various modes of atheism with exploration of the specific modes of voluntareity in faith. Instead he treated the "variant modalities of the will to atheism that lie at the root of the variant historical forms of atheism. ${ }^{.61}$ In Chapter 3, more than in his exposition in earlier chapters of how a quadriform structure in the problem of God emerged, Murray unearthed a contingent element in the voluntareity of unbelief. This was his historical consciousness of the origin of unbelief, and, I proposed, of belief as well.

In The Problem of Religious Freedom ${ }^{62}$ written in 1964 during Vatican II, Murray applied Bernard Lonergan's distinction between classicist and historical consciousness of truth to Catholic doctrine on religious liberty, and church-and-state relations. The council was moving toward affirmation of religious liberty and away from establishment as an exigency of faith. Did this imply departing from Leo XIII's denunciations of religious liberty? Murray argued for a continuity through development, a position that helped clear the way for approval of the council's Declaration on Religious Liberty, ${ }^{63}$ as is well-known. What has not been noticed is that in 1964 the Problem of God also had transposed the question of belief and unbelief from a classicist to a historically conscious mode of understanding. Murray placed the free, practical act of self-definition, the root of faith or unbelief, within the scope of historical consciousness.

Accordingly, he did not treat atheism as if it were monolithic and identically instantiated everywhere and at all times. He noticed a variety of species within the genus of modern atheism. A voluntary dy-

${ }^{61}$ Murray, The Problem of God 85.

62 Murray, The Problem of Religious Freedom; reproduced in J. Leon Hooper, ed., Religious Liberty: Catholic Struggles with Pluralism (Louisville, Ky.: Westminster/Knox, 1993) 127-97.

${ }^{63}$ Dignitatis humanae; see Flannery translation, Vatican Council II 799-812. 
namic was common to all. Every type took its rise in a pretheoretical, practical act of will. What differentiated the various types belonged to that act rather than to cultural conditions only as external circumstances. There was an internal circumstance. This left a gap in the statement of Murray's theory. How was it possible for a free act to counteract the teleogical structure of human existence? The following principle fills the gap. The will to atheism actualized a universal willto-exist in a particular, contingent mode marked by an absence, for some reason, of an adequate idea of the personal source and last end of human existence. If so, atheism too was a self-appropriation of the teleological structure of human existence and perhaps of human dignity, but involved a defective theoretical mediation of them. Atheism had always, however, a voluntary dynamic with a contingent cultural element. Denial of God was always denial of God understood in such and such a way.

This was the formal model for the structure of the voluntary dynamic in faith as well. Self-appropriation of the will-to-exist in this case correlated with an adequate idea of God who could then be affirmed as source and last end. Consequently, Murray's identification of variations in the voluntary dynamic of atheism permits an inference to variations in the voluntary dynamic in faith. And to the source of those variations in a contingent, concrete, culturally specific element. As was the case with atheism, this element pertains to the person's society, culture, and position in history; this element varies as do societies, cultures, and eras. The voluntary dynamic in faith always has both a universal and a particular aspect. The universal is the will-to-exist. The particular is a specification of this according to concrete goods loved and love for God surpassing and transforming the culturally qualified loves. Variety in cultures means variety in the voluntary dynamic of faith. Change in a culture means change in the contingent element, the cultural specification, in that dynamic. Should a society or culture undergo significant change, this would exert pressure within the act of faith on the previous contingent element, possibly inducing change in it. This means that the act of faith, even by believers holding the same body of truths and dwelling in a common culture, can evolve.

For example, by the end of The Problem of God historical consciousness of faith compels a new form of the ancient question about God's existence. Instead of "Does God exist or not?" and the biblical cri $d u$ coeur "Is God with us or not?" Murray asks, "Is the presence of God constitutive of man's historical existence or destructive of it?"64 $\mathrm{He}$ presupposed resolution of the theoretical question about God's existence into the practical, biblical search for God's presence. But then he reconceived divine presence. Biblical models of divine presence in theophanies or even in Emmanuel, "God-with-us," applied to Christ gave to the search a positive assurance that God was faithful to us

${ }^{64}$ Murray, The Problem of God 120. 
amid our trials and sufferings. However, this did not yet say much about human action toward social and political goals. That issue needed to be raised within the human-divine relationship. And so Murray recast the problem of God as a search for divine presence, as an efficacious being-with-us that enables human beings to stand forth in their freedom, to direct their actions and assume their role as shapers of society. So the question with which he closed The Problem of God was: Do God and faith enable people to assume socially constructive and nation-building tasks? If the answer is "yes," God and faith empower people to mobilize their human resources toward the common good in the temporal order. If the answer is "no," God and faith cripple this capacity. Which is it?

Arguing that God and faith were socially and politically constructive would provide a new form of biblical "knowledge of God" as "constitutive of man's historical existence." A negative answer was a new form of biblical "ignorance of God" alleging that divine presence destroys human historical agency. Each alternative was testable by recourse to history for evidence of individual and social action. Which alternative has enabled, which has destroyed, the ability of a person or a society to constitute their "historical existence"? Has acknowledging the presence of God produced the result that "a man may exist, 'stand forth' as a man in freedom and in human action"? Has "knowledge of God" or "ignorance of God" promoted a way of life and action "that alienates man from himself"? Has so destructive an effect come from "confession of God's presence in history and in man's consciousness"? Or from "the suppression of [God] from history and the repression of [God] from consciousness"?

Murray's implied answer is obvious from his critique of bourgeois atheism, Marxist communism, and Sartrean existentialism. Of course "knowledge of God" enabled a person or society to "stand forth in freedom and in human action." But raising the question does more than merely elicit that answer. The question surfaces a new contingency in the voluntary dynamic of faith. The contingent element has become the modern, Western appreciation of active responsibility for society and nation, a culturally inflected love for the common temporal good and the tasks proper to its achievement. Murray's question builds a determinate modality into faith or, contrarily, into atheism. His question was about modern faith, its answer pointed to a voluntary dynamic qualified by modernity's recognition of people's active participation in society and state. The love for God that moves faith is love by one who participates in the mores, goals, and values characteristic of a given cultural milieu and historical epoch. Only a love for God as last end who empowers people socially and politically converts, not annihilates, appreciation for the active contribution of every person toward the common temporal good.

The grace of faith affects finality toward God ad modum recipientis. This includes mediation of the finality by other goods people also love. 
Love for the Creator of culturally accessible goods undergoes transformation into love for God as last end and beatitude. The Creator can only be known and loved through a surpassing of cultural values and concrete goods. Such evaluations are culturally variable and historically mutable. This shifts the problem of God out of a classicist concept of objective truth and value into historical consciousness of the personal and social subjects who know and love. This means, and it is a discovery based on Murray's theology of faith, that the voluntary dynamic of faith, no less than any formulation of truth, is from the start codetermined by social and cultural particularities. ${ }^{65}$ The "root of faith" which is love for God has a contingent aspect drawing on and transforming the created goods appreciated by the believer's culture in a given era.

A conclusion from Murray is that the graced pia affectio referred to by theological tradition realizes itself always in a particular cultural mode which gives faith a historically variable concreteness. Cultural modes speak languages resonant with memories of goods loved and truths known. A culturally inflected love for God ascends from a society's appreciations for concrete goods. When moving the mind to assent to revelation, affection for the Creator is as new as the grace of faith and the arrival of the saving Word. But the newness also renews and transforms, heals and elevates already existent love for goods and truths available to a person in the culture. The will-to-faith is always a culturally inflected love for God that transforms but cannot bypass loves for whatever created goods the culture prizes.

For example, in his Confessions and in the light of faith, Augustine remembered prior loves and preceding judgments of truth. He recounted ascending through the truth and value of Cicero's Hortensius while also discerning its error and vice. So with the doctrine of the Manichees and Platonic teachings before he arrived at the definitive truth and value present in Christ, Bible, and Church. His act of faith and his theology bear the imprint of a long journey through his culture(s). Augustine's love for God as Creator interior to the act of belief had a contingent element that was specific to his historical heritage and cultural milieu. Similarly specific and contingent elements marked the love moving the faith of Martin Luther, Ignatius of Loyola, Teresa of Avila, Thérèse of Lisieux, Pope Leo XIII, and Pope John XXIII. The act of faith (not only its scriptural, liturgical, and doctrinal content) in fourth-century Milan, 16th-century Wittenberg, Avila, or Manresa differs from the ground up from an act of faith by an inhabitant of 19th-century Europe or of present-day Latin America, India, Poland, the Philippines, or Ireland. What Murray called the "root of faith," the voluntary dynamic whereby love for God moves assent to

\footnotetext{
65 That all knowing involves mutual codetermination by universal and particular is a main theme in the hermeneutical philosophy of Hans-Georg Gadamer; see, e.g., his Truth and Method (New York: Crossroad, 1982).
} 
revelation, has a contingent element as variable as cultures are diverse.

So from 1937 to 1964 Murray held that, as Langevin states, "faith implies a deliberate acceptance of the creaturely condition" because faith "supposes a surrender to the creative power of God, or a rejection of self-sufficiency." turely condition" as a bracing, salutary shock of confrontation with human limits. The limited human person, tempted to confuse openness to being with being infinite, comes-to-self by dismantling protection from the truth of finitude. And yet Murray understood voluntary acceptance of the creaturely condition more positively. Loving obedience to the Creator did more than, as a last gasp, admit finitude and acknowledge divine reality. It was acknowledging one's being-unto-God and consecrating oneself to God as the last end who is most loved. For Murray, creaturely dependence involved finality toward God and a variable, contingent element in love for the Creator that the grace of faith evoked.

At this point the axis of reflection shifts. The reading of Murray so far has pertained to his understanding of the genesis of faith or atheism. This was the main subject matter for his analysis fidei from 1937 through 1964. The hypothesis based on that turns more to habitual faith, the ordinary life of faith after its beginning. Murray's implied principle that the contingency of history and culture marks, though it does not entirely constitute, love for the Creator will be extended into consideration of the life of Catholic faith renewed by the influence of Vatican II. This is not to the claim that I am summing up his postconciliar thought, nor that this is the only way to conceive postconciliar reception of his theology of faith.

\section{A HYPOTHESIS: VATICAN II ALTERS HABITUAL FAITH}

My fundamental-theological hypothesis is that Vatican II affects the voluntareity of habitual faith. The cumulative impact of the event, documents, and charism of the council shifts attention from the freedom of faith to the dignity of the believer as imago $D e i^{67}$ This was not something Murray proposed. Rather, drawing upon the council's Pastoral Constitution on the Church in the Modern World, ${ }^{68}$ his postcon-

\footnotetext{
${ }^{66}$ Langevin, Dictionary of Fundamental Theology 310.

${ }^{67}$ Hermann J. Pottmeyer seems to have stated the case well: "The task that must be faced at the end of the second phase of the post-conciliar history of reception is to incorporate what is still binding in pre-conciliar theology into the newly acquired foundation, that is, into a communio ecclesiology and a Christian anthropology that calls for commitment to human dignity" ("A New Phase in the Reception of Vatican II: Twenty Years of Interpretation of the Council," in The Reception of Vatican II, ed. Giuseppe Alberigo et al. [Washington: Catholic University of America, 1987] 27-43, at 34).

${ }_{68}^{6}$ Gaudium et spes; see Flannery translation, Vatican Council II 903-1001.
} 
ciliar reflections on faith analyzed belief and atheism more subtly and in reference to the Church as subject. ${ }^{69}$ Though sustaining an interest in the interior source of faith and atheism, he looked primarily to their ecclesiological meaning. He gave qualified consent to "the theme of the belief of the unbeliever" and "the anonymous Christian." "There is," he came to see, "the theme of implicit faith ... in all ... of good will ... in all ... who are animated by the spirit of love."70 This issued in the ecclesiological conclusion that the Church remains semper reformanda, not only in individual members reforming their moral lives but in the Church as a whole in its life, teaching, and practice of faith. Cooperation with God's plan of salvation versus resistence to it, belief or unbelief, contend continually within the Church, not only in individual members here and there.

Murray's preconciliar fundamental theology yields a significant consequence when understood in light of conciliar anthropology. The Pastoral Constitution on the Church in the Modern World presents the main conciliar doctrine on the person, but many other documents, especially the Declaration on Religious Liberty, make a contribution. Together these two texts provide an adequate statement of the council's teaching on the human person as imago Dei. ${ }^{71}$ The latter can be read in reference to Murray's theology of faith no less than to his social ethics. The result is that the voluntareity of faith can be seen to involve human dignity.

With the Declaration on Religious Liberty the council gave official approval to a theme of modern culture which had been insufficiently appreciated in the Church. The bishops accepted as of God a typically modern consciousness of human dignity that for several hundred years

${ }^{69}$ See Murray, "Religious Freedom and the Atheist," in Hooper, Bridging 255-65, and "The Unbelief of the Christian," ibid. 266-78. Both postconciliar texts were published posthumously. Their chronological order is difficult to determine. When did Murray move from a polemical to a dialogical stance with atheism? Hooper finds grounds in The Problem of God for the shift to "a search for common theological ground with modern atheism" ("Theological Sources of John Courtney Murray's Ethics" 41). True, Murray paid grudging tribute to modern atheism for having "stated with rather appalling clarity, in a phrase calculated to shock us into awareness of its urgency ... that God is dead" (The Problem of God 120); but this is less than a search for common ground. Also, Murray's "The Right to Unbelief" denies that atheists have a civil right to propagandize for their view; this brief essay appeared as "Le droit a l'incroyance," Relations [Montreal] 22 (April 1962) 91-92 and is reproduced in Hooper, Bridging 231-36. Thus Murray developed his final views on atheism after Vatican II, not before.

${ }^{70}$ Murray, "The Unbelief of the Christian," in Hooper, Bridging 272.

${ }^{71}$ Murray did not develop the theme, but he did remark that the "first thing the Bible has to say about man is that he was made in the image of God" ("Freedom in the Age of Renewal," in Hooper, Bridging 183). And he understood this to mean inalienable, free self-possession and self-determination as the human prerogative making religion and morality possible. He referred to Aquinas's teaching that "Man . . . is made in the image of God'; and by image is here meant that man is intelligent, free in his power of choice, and of himself the master of himself . . the active source of what he does" (ibid. 183); he added that this drew upon a view common to John Damascene and the Greek Fathers. 
in the West had energized demands for religious liberty and, at least in England and the U.S., for limited, constitutional government. ${ }^{72}$ Modern consciousness of the dignity of the person grasped a truth "known through the revealed word of God and by reason itself." ${ }^{\text {"3 }}$ The Declaration, together with the Pastoral Constitution, gave new standing to human dignity as a theme in the life and mission of Catholicism, though in substance if not in terminology it had long been a part of the Church's social teaching. At a minimum the two documents clarified the basis for subsequent ecclesial and papal commitment to the human-rights agenda and placed that commitment on common ground with all who struggle for human dignity and human rights. Moreover, the affirmation of human dignity illuminated other doctrines, so that the processes of renewal transmit that affirmation in many pastoral accents, from respect for the mission and role of the laity to liturgical renewal in the direction of active participation and social ministries promoting human rights. The argument is that the council's commitment to human dignity has a profound effect on the contingent element in love for God that moves faith. The council initiated a renewal in the very act of believing as well as refined elements in the content believed. ${ }^{74}$ This occurred because conciliar orientation to human dignity modifies the meaning of the creaturely love for God internal to faith.

The key to conciliar teaching on the Creator-creature relationship and the dignity of the human creature is the theme of the imago Dei. Anthony Erhueh does not hesitate to say that the "imago Dei is the basis and foundation of human dignity" in the Pastoral Constitution. ${ }^{75}$ Its first chapter presents God as the Creator whose imago are the socially related persons whose dignity is spelled out in some of its main elements by the chapter. The Declaration on Religious Liberty grounds religious liberty in that dignity. While the imago Dei motif is undoubtedly the key to the anthropology of the Pastoral Constitution, its coherence has been under review. ${ }^{76}$ Discussion turns on the difference between a creation-centered and a christocentric account of humanity

${ }^{72}$ Murray understood this "modern consciousness" as an emergent grasp of the natural law and as a prompting of reason; see The Problem of Religious Freedom 17-19.

${ }^{73}$ Declaration on Religious Liberty; see Flannery translation, Vatican Council II 800.

${ }^{74}$ M. Basil Pennington finds that the Declaration on Religious Liberty summons believers onto a path out of acedia, "an insidious spiritual sloth" against which the early Church too had struggled. He points to the exhortation, "Let them form [people] too who will be lovers of true freedom ... . who will come to decisions on their own judgment and, in light of truth, govern their activities with a sense of responsibility ... willing always to join with others in cooperative effort" (Vatican II: We've Only Just Begun [New York: Crossroad, 1994] 8). This conciliar exhortation, he observes, invites Catholics to personal development in their faith.

${ }^{75}$ Vatican II: Image of God in Man (Rome: Urbaniana University, 1987) 188.

${ }^{76}$ See Walter Kasper, "The Theological Anthropology of Gaudium et Spes," Communio 23 (1996) 129-40; and David L. Schindler, "Christology and the Imago Dei: Interpreting Gaudium et Spes," Communio 23 (1996) 156-84. 
(nos. 12 and 22). Are they integrated? Do they generate alternative visions of postconciliar Catholicism? Schindler has argued that they do. It seems more likely, however, that the Christology of no. 22 relies upon "a theological conception which assumes the unity of the orders of creation and redemption in salvation history," as Kasper says, ${ }^{77}$ than that sections 12 and 22 of the Pastoral Constitution stand in irreconcilable tension. ${ }^{78}$ Yet absence of a fully conceptualized theological synthesis does not stem necessarily from a conflicted faith-understanding.

Agreement by the Church on which books constituted the canon of the New Testament, for instance, expressed its recognition of a basic harmony among Christologies as diverse as those of Mark, Matthew, Luke, and John. Nor did Nicaea, Constantinople, and Chalcedon state a complete synthesis of all christological tendencies in the New Testament. On this and other bases there is reason to doubt the hermeneutical principle that a significant theological difference has to be conceived first and last as the product and source of irremediable theological conflict. For that reason it seems gratuitous for Schindler to contend that the difference between nos. 12 and 22 generates a postconciliar antithesis between a christocentric theology of creation adopted by Pope John Paul II and a "theistic" view lending itself to an unhappy alliance between "Anglo-American liberalism and conciliar Catholicism."79 His uneasiness about certain emphases in the Church's teaching may nonetheless highlight the need for further thought and synthesis. But his exposition has not argued conclusively either that there is conflict between nos. 12 and 22 in the Pastoral Constitution or that the difference has generated division in postconciliar American Catholicism. That a difference in textual foci might express a real though unformulated unity receives no consideration. Yet why cannot those two sections witness to a faith-understanding whose comprehensive unity is real (both are scriptural) but which may elude conceptual synthesis in this (or any) text? The unity immanent in the multitude of deeds and words in divine salvation and revelation is real, but that is not the same as saying that the Church's theological understanding of it at any given time (or ever) will be more than a deepening grasp of a whole which remains an asymptotic goal for theology. The whole has not yet been historically realized either.

Therefore the assumption will be made here that the council does not teach a divided and divisive anthropology in the Pastoral Constitution nor, in conjunction with it, in the Declaration on Religious Liberty. Coherence in conciliar anthropology but not necessarily a single, clear, synthetic concept will be presumed in what follows. According to both sections of the Pastoral Constitution, the proto-human pair in Genesis

\footnotetext{
${ }^{77}$ Kasper, "The Theological Anthropology of Gaudium et Spes" 137.

${ }^{78}$ Schindler, "Christology and the Imago Dei" 156-59.

79 Ibid. 166.
} 
1-2 were created in the image of God the Creator (imago Dei) ${ }^{80}$ The council clearly adopts a relational understanding of the imago. It puts behind it past designations of reason or dominion as the most God-like attribute and so as the seat of human likeness to God. Instead, the council presents the imago, as Joseph Ratzinger early observed, in three relationships. First and foremost, an openness for companionship with God in which a person, "stands in immediate relation to God ... [and] does not have to do with God indirectly through ... work and ... relations with ... fellow [human beings]." ${ }^{81}$ Immediacy in relating to God is essential to the imago $\mathrm{Dei}^{82}$ The immediacy comes to expression directly in reverence for and obedience to God. But it also gives rise to profound community between man and woman and to a relationship with earth that shares in divine dominion on behalf of divine care for creation. It is not one or another attribute or aspect that expresses likeness to their Creator, but the whole existence of the proto-pair.

The imago Dei is realized in a proto-pair of deeply related human persons, not in a set of monads unencumbered by the givenness of God, their community, and earth. In that sense the imago Dei is not complete in one self as if one human being by himself was the imago. Rather the likeness to God of any person exists within a generic likeness shared by family (society, human species) and expressed in relation to earth (cosmos). Adam and Eve are not, then, simply two individuals at the beginning of a series of further individuals but precisely symbolic and representative of all humanity.

The protological imago of the Pastoral Constitution no. 12 is not negated or contradicted but fulfilled by the advent of Christ who is the foremost and eschatological image of the God of Israel. Only in Christ, Alpha and Omega, are humans revealed to themselves. "For Adam, the first man, was a type of him who was to come." 83 The truths about human dignity enunciated in Chapter 1 of the Pastoral Constitution and by the Declaration on Religious Liberty find their "source and their most perfect embodiment" in Christ. ${ }^{84}$ Christ restored to humanity a likeness to God disfigured by sin. Participation in Christ does more

${ }^{80}$ Gaudium et spes no. 22 speaks about "Adam, the first man" and declares that "all the truths mentioned so far [in Chapter 1, including no. 12] should find in him [Christ] their source and most perfect embodiment." Among "all the truths" is the meaning of the dignity of the human person announced in the very title to Chapter 1, "The Dignity of the Human Person," which no. 22 brings to a conclusion.

${ }^{81}$ Joseph Ratzinger, "The Dignity of the Human Person," in Commentary on the Documents of Vatican II, ed. Herbert Vorgrimler, vol. 5 (London: Burns \& Oates, 1969) 123.

${ }_{82}$ Luis Ladaria, S.J., warns against restricting conciliar doctrine on humanity in God's image" to a theology of creation alone, since as Irenaeus taught, "Adam does not explain Christ; Christ explains Adam." "Humanity in the Light of Christ in the Second Vatican Council," in Vatican II Assessment and Perspectives: Twenty-five Years after (1962-1987), ed. René Latourelle [New York: Paulist, 1989] 386-401, at 390).

${ }^{83}$ Gaudium et spes no. 22.

${ }^{84}$ Gaudium et spes also states that "Christ, ... in the very revelation of the mystery of the Father and his love, fully reveals man to himself and brings to light his most high 
than grant believers a new soteriological status; it inserts them into a dynamic process wherein the Spirit conforms the Church and believers to Christ. Consequently, the teaching on human dignity in the Declaration on Religious Liberty and the Pastoral Constitution supports the following inference. Human dignity, personal conscience, and a rightful autonomy underlying religious liberty belong to the dependent creaturely condition established through and in view of Christ.

Because the imago Dei, according to conciliar teaching, has personal dignity, relational autonomy, and the right to religious liberty, these aspects of human existence are recognized as coming from and in some way serving as a path to the Creator. Conciliar amplification of meaning for the imago expands practical knowledge of the Creator who is loved unto belief. The knowledge enters into the voluntareity of habitual faith. Entry occurs by assimilation of the effects from conciliar renewal and, to the extent that it occurs, by familiarity with the conciliar doctrine. God is loved as source and last end not solely of contingent existents, cosmic order, and all legitimate authority, but above all of intrinsically worthy human existence. Conciliar orientation to human dignity imparts a new quality to reverent love (pia affectio) for the Creator internal to the habit of faith. Affirmation of human dignity characterizes the believer's self-understanding and awareness of the Creator. This respecified pia affectio within the interiority of faith begins to guide faith-understanding and the life of faith along ways respectful of conscience, personal dignity, relational autonomy and, in society, religious liberty. ${ }^{85}$ This is faith being true to its renewed voluntary dynamic.

The habit of faith becomes, while also responding to the Word of God, a hearing of the believer's own existence-but not as if in isolation from others or from the physical cosmos-as a created word of God. Of course, this hearing is indirect in comparison with the material object of faith, that is, the gospel believed, preached, and taught by the Church. This hearing of creation within believing the gospel is how Vatican II initiated and continues to support a profound integration of the reality of the imago Dei into the voluntary dynamic of habitual faith. The voluntareity of postconciliar faith is a love for God ascending

calling" (no. 22). This statement, Schindler notes "repeats almost verbatim a statement by Henri de Lubac in Catholicism (1938)" and "offers the best way into the pope's [John Paul II's] view of the autonomy of creation" ("Religious Freedom, Truth and American Liberalism" 704). In order to prevent any implication of polarity with, e.g., Karl Rahner's theology, it should be noted that Rahner's transcendental christology involves a christocentric anthropology; see The Foundations of Christian Faith: An Introduction to the Idea of Christianity, trans. William V. Dych (New York: Seabury, 1978).

${ }_{85}$ Pope John Paul II teaches a gentle reverence for the human mind seeking truth. He encourages Catholics to await the next millennium with repentent humility for any past irreverence the Church has shown to persons in their search for truth. "Another painful chapter of history to which the sons and daughters of the Church must return with a spirit of repentence," he reminds us, "is that of acquiescence given, especially in certain centuries, to intolerance and even violence in the service of truth" (Tertio millenio adveniente [Vatican City: Vatican City Press, 1994] nos. 35, 41; emphasis in the original). 
from respect for our common humanity that has eyes open to its dignity as imago Dei.

As a result, faith after Vatican II, more than faith after Vatican I, has become a performed participation in the truth of human dignity. ${ }^{86}$ This is why the spiritual life of faith has an ecclesiastically mediated impetus toward personal appropriation of the imago Dei. The grace of faith, we are reminded by Murray's fundamental theology, evokes a love for the Creator as last end that simultaneously is an act of human self-recognition and personal dedication to God. The pilgrimage of faith, consequently, brings a gradual, faith-inspired appropriation of a believer's own participation in the imago Dei precisely as a concomitant to deepening faith. ${ }^{87}$ The grace of faith blesses the creational conferral of (limited) authority for personal self-direction. Within the renewal of habitual faith under the renewing impulse of the council there takes place a loving obedience to the Creator as first cause and last end in hearing the creational word of God pronounced in the language of the teleological structure and intrinsic dignity of the human person.

If my hypothesis on Vatican II and faith is sound, one can conclude that the work of the Holy Spirit in conciliar renewal produces an unofficial, often inconspicuous, but personal appropriation of human dignity within the dynamic of habitual Catholic faith. This result, which may appear as consciousness of moral agency, stems not primarily from compliance with the valuable external teaching of the magisterium on the importance of human dignity, nor from adherence to liberal ideology, but from creaturely acceptance of the inner word on human dignity in the voluntareity of faith itself. The immanence of that word in ordinary faith is a reason for saying that Catholic faith is inseparable from the Church's commitment to fostering the realization of human dignity through respect for human rights. According to this view, then, the Church's postconciliar commitment to the humanrights agenda springs from a graced love for the Creator, educated into new appreciation for the imago Dei, moving the assent of faith.

${ }^{86}$ In historical-theological perspective, observes Avery Dulles, the understanding of faith at "Vatican II did not directly follow in the line of development that stretches from the Council of Trent, through Vatican I and the anti-Modernist documents to Humani generis. Without contradicting this recent tradition Vatican II took a more personalist, vitalist approach ..." (Assurance 139).

87 The recent catechism incorporates conciliar affirmation of human dignity into its teaching on faith when it states that "believing' is a human act, conscious and free, corresponding to the dignity of the human person" (The Catechism of the Catholic Church no. 180 [Liguori, Mo.: Liguori, 1994] 48). That statement leads the way to further consideration of faith and dignity. The catechism adds that " believing' is an ecclesial act. The Church's faith precedes, engenders, supports, and nourishes our faith. The Church is the mother of all believers" (no. 181, ibid.) This does not mean that the Church's faith substitutes for the act of belief by members, as if they had no real access to God through the Church but access only to the Church which could believe on their behalf. The Church understands the condition of faith in an infant receiving baptism as a temporary, initial reality which the dynamic of faith urges into development. The relation to God in a baptized infant cannot be taken as a norm. 